
terms of the Creative Commons Attribution licence (https://creativecommons.org/licenses/by/4.0/), which permits unrestricted re-use, distribution, and reproduction in any medium, provided the original work is properly cited.

\title{
Sowing Seeds: Garden Festivals and the Remaking of British Cities after Deindustrialization
}

\section{Sam Wetherell}

\begin{abstract}
This article explores one of the strangest and most spectacular urban policies in postwar Britain: national garden festivals. Initiated by Margaret Thatcher's government, the festivals were vast state-sponsored gardening shows held in deindustrializing cities to reclaim derelict land for the property market. A festival was held every other year between 1984 and 1992 in a different city, five in all. The garden festivals showcased a new kind of urbanism, one that would change the ways that British cities related to nature, to capital, and to the wider world. First, they evinced a unique type of environmental politics - an implicit critique of urban industrial landscapes that was distinct from both the emerging critique of climate change and from older ideas about conservation. Second, they emerged at a time when the attraction of private capital was becoming increasingly central to urban regeneration. The festivals were at the forefront of this turn, outsourcing their events to corporate sponsors. Finally, the festivals offered an idiosyncratic, incoherent version of globalization. They courted a global pool of tourists and capital and invited delegations from across the world to plan events while, in many instances, reinforcing a preexisting racialized social hierarchy shaped by imperial legacies.
\end{abstract}

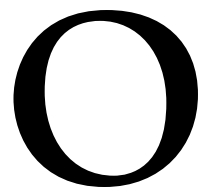

ne of the most spectacular, conspicuous, and ambitious attempts to remake Britain's built environment in the late twentieth century was also fleeting and transient and has perhaps been largely forgotten. Between 1984 and 1992, spaces left exposed by the receding tide of Britain's industrial economy-disused docklands, abandoned steel works, empty warehouses, and coal depots-were transformed into vast, temporary garden shows that were visited by millions. National garden festivals were first announced in 1981 by Margaret Thatcher's environment secretary, Michael Heseltine, as an explicit response to a summer of widespread unrest in Liverpool and other major British cities. Along with enterprise zones, urban development corporations, and derelict land grants, garden festivals were intended to help solve the crisis of the "inner city"-an object of policy and concern that linked structural unemployment with crime, public order, race, and infrastructural deterioration. ${ }^{1}$ There were five festival sites

Sam Wetherell is a lecturer in the history of Britain and the world at the University of York. He thanks the organizers and participants of a roundtable on the British inner city held at the University of Leicester in April 2019 for their thoughts and comments on an early draft of this article. He thanks also Guy Ortolano, James Vernon, Maureen Garvie, Elyse Bell, and Trevor Jackson for being brilliant and compassionate readers at various stages in its life. Please direct any correspondence to sam.wetherell@york.ac.uk.

${ }^{1}$ For the emergence of the "inner city" as an object of politics, see Aaron Andrews, "Decline and the City: The Urban Crisis in Liverpool, c. 1968 to 1986" (PhD diss., University of Leicester, 2018); Otto 
in all-Liverpool (1984), Stoke-on-Trent (1986), Glasgow (1988), Gateshead (1990), and Ebbw Vale (1992). ${ }^{2}$ Each was a discrete space with turnstiles and a modest admissions price, open continuously for the summer months. Inside, there were gardens, of course, but also themed pavilions, model railways, live music shows, food stands, children's playgrounds, and even, in the case of Glasgow, a rollercoaster. When the festivals eventually closed, it was intended that the land would be made available to developers who had previously been deterred by the high cost of clearing derelict buildings and cleaning toxic land.

The festivals were spectacularly popular, each attracting more than two million visitors. Even accounting generously for repeat visits and overseas tourists, visitor numbers suggest that at least one in every ten Britons visited a national garden festival during these years. ${ }^{3}$ They were comparable in size, scale, and ambition to the 1851 Great Exhibition or the 1951 Festival of Britain, events the festivals consciously alluded to. Their inspiration came, in part, from the West German Bundesgartenschan (federal garden shows), which had been held every other year since 1951 to reclaim land in cities damaged during the war. ${ }^{4}$ For their size alone, British garden festivals are worthy of the attention of historians. In this article, however, I argue that national garden festivals help us understand some of the distinctive features of a new kind of urbanism that emerged in late twentieth-century Britain. The events reveal the important ways in which the environment, the economy, and the social order of British cities were reimagined in the 1980s and 1990s.

Many of the constituent elements of the late twentieth-century British city have been charted by historians. Some have looked at the ways that homeownership,

Saumarez Smith, "Action for Cities: The Thatcher Government and Inner-City Policy," Urban History 47, no. 2 (2020): 274-91; Otto Saumarez Smith, "The Inner City Crisis and the End of Urban Modernism in 1970s Britain," Twentieth Century British History 27, no. 4 (2016): 578-98. For race and the "inner city," see Kennetta Hammond Perry, London Is the Place for Me: Black Britons, Citizenship, and the Politics of Race (Oxford, 2015); Kieran Connell, Black Handsworth: Race in 1980s Britain (Oakland, 2019); Camilla Schofield and Ben Jones, "'Whatever Community Is, This Is Not It': Notting Hill and the Reconstruction of 'Race' in Britain after 1958," Journal of British Studies 58, no. 1 (2019): 142-73. Work by Divya Subramanian, Jac St. John, and Claire Wrigley in this area is forthcoming.

${ }^{2}$ For an overview of the national garden festival movement, see Andrew C. Theokas, Grounds for Review: The Garden Festival in Urban Planning and Design (Liverpool, 2004); Rodney D. Beaumont, "Garden Festivals as a Means of Urban Regeneration," Journal of the Royal Society of Arts 133, no. 5346 (1985): 405-21.

${ }^{3}$ The figure of one person in every ten is a rough estimate. While there were close to fifteen million total visits to the five events (Liverpool, 3.4 million; Stoke-on-Trent, 2.2 million; Glasgow, 4.3 million; Gateshead, 3 million, Ebbw Vale, 2 million), these numbers include repeat visits. The sale of season tickets at many events, and a handful of news stories of visitors claiming to have attended every day the festival was open (in Glasgow and in Ebbw Vale), suggests that repeated visits were not insignificant but probably did not amount to more than a third of all visits. With the population of Britain between 1981 and 1991 being somewhere between fifty-six million and fifty-eight million people, the figure of one in ten is a likely, if not even a conservative one. For attendance figures for the Liverpool, Glasgow, and Stoke-on-Trent events, see Department of the Environment, An Evaluation of Garden Festivals (London, 1990). For Gateshead, see Tony Henderson, "Gateshead National Garden Festival: 25 Years since the Event on Tyneside," Evening Chronicle (London), 13 May 2015. For Ebbw Vale, see Lewis Smith, "The Scorched Legacy and Sorry Sight of Ebbw Vale's Festival Park,” Wales Online, 27 June 2020.

${ }^{4}$ One year before the announcement of British National Garden Festivals, the Department of Environment conducted a detailed in-house report on German bundesgartenschau. See "German Federal Garden Shows," 11 March 1980, National Archives, AT 42/75. (Hereafter this repository is abbreviated as TNA.) 
and the extension of private capital ownership more broadly, became one of the core elements of Margaret Thatcher's political program. ${ }^{5}$ Others have looked at the emergence of a new urban policy landscape in the 1980s. ${ }^{6}$ Many have examined these topics within the broader context of deindustrialization since the late 1960 s. $^{7}$ Historians have written about subjects such as race, sex work, community formation, and spaces of political resistance in British cities whose economies were being transformed in the 1980s and 1990s. ${ }^{8}$ These transformations were inchoate and hybrid. Private homeownership had to be awkwardly and often unsuccessfully retrofitted into dense housing projects characterized by shared public space and municipal heating sources. Signature urban policies such as enterprise zones were substantially watered down-never becoming the fantastical libertarian power vacuums their creators envisaged. ${ }^{9}$ National garden festivals, however, offered a blank, albeit transient slate on which the city could be remade from the soil up in response to a perceived crisis of economic and infrastructural obsolescence. Although a variety of different agents - urban and regional development corporations, local authorities, newly formed companies, private architecture firms - had roles in planning and organizing the five festivals, each festival offered a similar vision of the urban future, one that was

5 Aled Davies, "Right to Buy': The Development of a Conservative Housing Policy, 1945-1980,” Contemporary British History 27, no. 4 (2013): 421-44; Alison Ravetz, Council Housing and Culture: The History of a Social Experiment (London, 2001), 193-237; Guy Ortolano, Thatcher's Progress: From Social Democracy to Market Liberalism in an English New Town (Cambridge, 2019), esp. 212-53; Amy Edwards, Financial Times: Investment Culture in Late Twentieth Century Britain (forthcoming, Berkeley: University of California Press).

${ }^{6}$ Brett Christophers, The New Enclosure: The Appropriation of Public Land in Neoliberal Britain (London, 2018); Daniel Stedman Jones, Masters of the Universe: Hayek, Friedman and the Birth of Neoliberal Politics (Princeton, 2012), 273-325; Sam Wetherell, "Freedom Planned: Enterprise Zones and Urban Non-planning in Post-war Britain," Twentieth Century British History 27, no. 2 (2016): 266-89; Saumarez Smith, "Action for Cities"; Theokas, Grounds for Review, 158.

${ }^{7}$ For example, regarding Liverpool, see Alice Mah, Port Cities and Global Legacies: Urban Identity, Waterfront Work, and Radicalism (Basingstoke, 2014). Regarding Glasgow, see Jim Phillips, Valerie Wright, and Jim Tomlinson, "Being a 'Clydesider' in the Age of Deindustrialisation: Skilled Male Identity and Economic Restructuring in the West of Scotland since the 1960s," Labour History 61, no. 2 (2020): 151-69. See also Jim Tomlinson, "De-industrialisation Not Decline: A New Meta-Narrative for Post-war British History," Twentieth Century British History 27, no. 1 (2016): 76-99; Christopher Lawson, "Making Sense of the Ruins: The Historiography of Deindustrialisation and Its Continued Relevance in Neoliberal Times," History Compass 18, no. 8 (2020): el2619, https://doi.org/10.1111/hic3.12619.

${ }^{8}$ For race, see Perry, London Is the Place for Me; Connell, Black Handsworth; Rob Waters, Thinking Black: Britain, 1964-1985 (Oakland, 2019). For sex work, see Judith R. Walkowitz, "Feminism and the Politics of Prostitution in King's Cross in the 1980s," Twentieth Century British History 30, no. 2 (2019): 231-63. For community formation, see Radhika Natarajan, "Organizing Community: Commonwealth Citizens and Social Activism in Britain, 1948-1982" (PhD diss., University of California, 2013); Jon Lawrence, $\mathrm{Me}, \mathrm{Me}, \mathrm{Me}$ : Individualism and the Search for Community in Post-war England (Oxford, 2019); Ortolano, Thatcher's Progress, 143-84; Sam Wetherell, "Painting the Crisis: Community Arts and the Search for the 'Ordinary' in 1970s and '80s London," History Workshop Journal 76, no. 1 (2013): 235-49. For some very different works on resistance to the late twentieth-century British state grounded in urban space, see Daisy Payling, "Socialist Republic of South Yorkshire': Grassroots Activism and Left-Wing Solidarity in 1980s Sheffield," Twentieth Century British History 25, no. 4 (2014): 602-27; Lucy Delap, "Feminist Bookshops: Reading Cultures and the Women's Liberation Movement in Great Britain, c. 1974-2000," History Workshop Journal 81, no. 1 (2016): 171-96; Adam Page, "Appropriating Architecture: Violence, Surveillance and Anxiety in Belfast's Divis Flats," Journal for Architectural Knowledge, no. 10 (2017): 90-112.

9 These are points I have made in more detail elsewhere. See Sam Wetherell, Foundations: How the Built Environment Made Twentieth-Century Britain (Princeton, 2020); Wetherell, "Freedom Planned." 
overseen by the watchful and approving eye of a Conservative government in Westminster. They were demonstrative, even utopian spaces, distillations, as we will see, of new urban practices that, in diminished form, would be generalized throughout Britain by the century's end. Just as the urbanist Rosemary Wakeman has argued that many new towns built by social democratic states across the world in the middle of the twentieth century were deus ex machinas for their regimes, shortcuts through time to a more modern future, garden festivals offered immanent critiques of the crumbling industrial cities in which they were embedded and hastily attempted to resolve their contradictions in a burst of floral exuberance. ${ }^{10}$

Focusing on the Liverpool, Glasgow, and Ebbw Vale festivals but drawing on all five events, this article is a cultural history that identifies three emerging features of the late twentieth-century city that garden festivals brought together. Each of these features showcased a new way of thinking about the meaning and purpose of urban space in Britain. First, garden festivals promoted what I call a market environmentalism, a conservative critique of industrial planning and top-down urban redevelopment that saw no tension between environmental politics and the expansion of the free market. Second, garden festivals were notable for their entrepreneurial approach to the management of urban space. Individuals and organizations were encouraged to bid for small pockets of space on the festivals' grounds, and much of the festivals' content and infrastructure was outsourced to a dizzying array of corporate sponsors. This type of entrepreneurial government superseded any master narrative or pedagogical function for the festivals. Finally, the festivals, and in particular the 1984 Liverpool International Garden Festival, showcased a postimperial internationalism that saw a wild and random juxtaposition of different events and exhibitions from different nations in an attempt to make new connections between British cities and the wider world. This cosmopolitanism repressed an urban social order that was profoundly structured by race in places like Liverpool, a city whose associations with empire and whose history of black, Chinese, and Irish migration were largely overlooked by festival planners. These three themes (market environmentalism, entrepreneurial government, and postimperial internationalism) are, I argue, what make the late twentieth-century British city distinctive. Despite the fact that the festivals mostly failed as strategies for the long-term rehabilitation of their respective neighborhoods, the greening of derelict spaces, the privatization of infrastructure, and the courting of global pools of capital and tourists have profoundly shaped the look and feel of cities in Britain and across the world after deindustrialization. National garden festivals are the first instance in which we can see these three new ways of thinking about the city working together to provide a coherent alternative to the perceived environmental, economic, and social obsolescence of Britain's built environment.

\section{MARKET ENVIRONMENTALISM}

In the distinctive way in which they squared the human and the natural, the organic and the urban, national garden festivals were an implicit critique of Britain's nineteenth- and twentieth-century industrial landscape. They presented a vision of

\footnotetext{
${ }^{10}$ Rosemary Wakeman, Practicing Utopia: An Intellectual History of the New Town Movement (Chicago, 2016), 49 .
} 
modernity that was grounded in nature and spontaneity rather than artifice and industry. Speaking in Liverpool at the opening of its festival on 2 May 1984, for example, the queen noted that while "plants wither and die . . . with the coming of Spring growth begins again ... garden exhibitions blooming on this site are symbolic of what we all wish for Liverpool."1l Unlike the notionally obsolete industrial landscapes in which the festivals were embedded, these events were to be clean and verdant spaces, powerful metaphors for renewal and growth. However, as highly artificial environments, engineered on former industrial land that had been urbanized over centuries in the past, the festivals were hardly an exercise in conservation. Rather, they offered their visitors a cartoonish hyper-reality, a simulacrum of nature built to smother the unsightly polluted relics of Britain's industrial past and mobilized as a critique of urban industrial life.

All five national garden festivals were held in parts of Britain that were suffering from the economic and environmental consequences of deindustrialization. Liverpool had been particularly affected by the collapse of dock work. Between the late 1950s and the opening of the festival, the docks, once the city's largest employer, had lost fifteen thousand jobs. ${ }^{12}$ In Ebbw Vale, the town's steel mill, by far the town's largest employer, had gradually ceased production through the 1970s, becoming a center for tin plating before closing in stages in the 1980s and 1990s. Likewise Glasgow, Stoke-on-Trent, and Gateshead had all suffered substantial job losses in the 1960s, 1970s, and 1980s. In all of these places, "dereliction," usually in the form of empty industrial buildings and contaminated land, had been identified as a target for policy. ${ }^{13}$

Each festival was preceded by several years of extensive preparation, during which buildings were demolished and soil was detoxified. The Liverpool festival took place on a stretch of derelict land in the southeast of the city. Most of the site had once belonged to the Herculaneum Dock, which had opened in 1866 and closed in 1972. The remainder was mostly taken up by a large garbage tip owned by the city since 1950. Like many of the Victorian docks that once dominated Liverpool's waterfront, the Herculaneum Dock's demise had come from a new breed of container ship, which was increasingly difficult to dock in the relatively narrow and fast-flowing Mersey estuary. The site was prepared at a Stakhanovite pace by the Merseyside Development Corporation, the state-appointed body in charge. ${ }^{14}$ While German Bundesgartenschau were usually designated eight years in advance of festival openings, the preparations for the Liverpool festival took just nineteen months. ${ }^{15}$ During that time, the dock was dismantled and reconstituted along with hundreds of acres of land reclaimed from the Mersey. The reclamation involved the removal of 700,000 tons of contaminated silt and its replacement with an equal amount of

${ }^{11}$ Anne Jones, 50,000 Bluebells: The Story of Liverpool's International Garden Festival (Peterborough, 1984), 94.

12 Andrews, "Decline and the City," 58; Brian Marren, We Shall Not Be Moved: How Liverpool's Working Class Fought Redundancies, Closures and Cuts in the Age of Thatcher (Manchester, 2018), 31-52.

${ }^{13}$ In Liverpool, for example, the festival came in the wake of more than a decade of discussions about how to reclaim disused dock buildings. Aaron Andrews, "Dereliction, Decay and the Problem of De-industrialization in Britain, c. 1968-1977," Urban History 47, no. 2 (2020): 236-56.

${ }^{14}$ Theokas, Grounds for Review, 146-48.

15 Theokas, 146. 
fresh sand dredged from the banks of the river. ${ }^{16}$ The work became a kind of performance, part of the self-made mythology of the festival. Some of the original material of the derelict site was recycled for use in the event. The wooden jetties that once formed the dockland site were turned into benches, while it was hoped that the methane drained from a toxic landfill would heat the festival hall for several years. ${ }^{17}$ A small patch of the unused industrial land that had once occupied the festival's grounds was left in place, in order to show "just how depressingly derelict land can be, and what can be done with it." 18

During the preparations for the 1988 Glasgow festival, the process of reclamation was no less impressive. As with Liverpool, the festival grounds included a stretch of disused dockland on the River Clyde, located at the center of the city. As with Liverpool, new land was created in the river by dredging and sculpting 300,000 tons of sand. ${ }^{19}$ Also as in Liverpool, this process was equal parts necessity and performance. For more than two years before the event, Glasgow residents were kept up to date on the process of reclamation and planning for the festival. Lessons on the excavation and remodeling of the site were circulated among schools to be taught to children. ${ }^{20}$ When the festival opened, visitors were frequently encouraged to make mental comparisons between the present and past of the festival grounds, with one exhibit asking visitors to "recall for a moment that the entire Festival site was once a huge dockland complex." 21 Promotional material spoke breathlessly of an awe-inspiring, almost magical transformation: "Almost incredibly, a wasteland of 120 acres on the south bank of the River Clyde has been turned into a Disneylike paradise." 22

The spectacular environmental improvement works conducted in advance of all five festivals were touted as partial and short-term solutions to local unemployment problems. The festival organizers hired local workers to demolish buildings, clear land, and plant trees and flowers. Some workers may have found themselves in the unusual position of having to demolish their own former workplaces. However, in most instances, the new jobs created were temporary and had little impact on local unemployment figures. Liverpool's festival, for example, which featured perhaps the most ambitious land reclamation project of the five festivals, created just three hundred new jobs in a city that, the year the festival opened, recorded an unemployment rate of nearly 20 percent. ${ }^{23}$ The work was not, nor was it intended to be, a longterm solution to the significant loss of stable employment in these areas of the country. Indeed, promotional literature for the Liverpool Garden Festival boasted of the success of its labor regime, one that was no doubt cemented by the precarity

\footnotetext{
${ }^{16}$ Jones, 50,000 Bluebells, 9.

${ }^{17}$ Department of the Environment, An Evaluation of Garden Festivals, 7.

18 "[Liverpool] Festival Guide," promotional pamphlet, 1984, Liverpool Records Office, 712.50942753 INT, 107.

19 "Can We Interest You in a Few Statistics?" and "Sediment Gets the Treatment," Glasgow Herald, 28 April 1988.

${ }^{20}$ Glasgow Garden Festival, Festival Focus: Keeping You in Touch with the Glasgow Garden Festival 1988 (Glasgow, 1988).

${ }^{21}$ Glasgow Garden Festival, Glasgow Garden Festival '88 Souvenir Edition (Glasgow, 1988), 12.

${ }^{22}$ Robert Reid, "Marketing Glasgow," Landscape Design, June 1988.

${ }^{23}$ Marren, We Shall Not Be Moved, 34.
} 
of contracts and the scarcity of work, noting that not a single day of festival preparation had been lost due to strike action. ${ }^{24}$

The repressed industrial prehistory of these spaces frequently returned, at times as nostalgia and at times as parody, flaunting the extremity of the transformation effected by the festivals. The Ebbw Vale Garden Festival, for example, invoked the former coal fields that dominated the town's nearby landscape by having schoolchildren line the entrance to the site on opening day dressed as miners with hardhats and soot-covered faces. ${ }^{25}$ A "mine-based" amusement ride was also proposed. ${ }^{26}$ Meanwhile, all five festivals boasted some form of kitsch nineteenth- or early twentiethcentury form of transportation. The Liverpool festival featured a steam-powered miniature railway that took visitors to the various sections of the site with a full signaling system, bridges, level crossings, and even a tunnel. The Glasgow site was serviced by a series of restored early twentieth-century tramcars, relics from the city's municipal tram system that closed in 1962. ${ }^{27}$ At Stoke-on-Trent, it was intended that festival visitors would participate in mock industrial workshops, including some in pottery making. ${ }^{28}$ Garden festivals erased the industrial legacy of many parts of Britain, only to selectively revive it in highly aestheticized and theatrical forms.

Aesthetic improvement, even more than the attraction of new jobs and capital into inner cities, was to be the yardstick against which festival planners would measure success. Liverpool's festival was billed as an opportunity to initiate a transatlantic conversation about what was increasingly termed "green" urbanism in postwar cities. The city hosted a conference of urban leaders from thirty British and twenty American urban planning organizations to discuss means of urban regeneration through park building and tree planting. For the attendees, beauty rather than pollution or sustainability was the key issue, with the conference's editorial blaming ugliness and dereliction for suburbanization and capital flight from British and American cities. ${ }^{29}$ With these aims in mind, beautification was subjected to strange forms of quantification. In 1990, the Department of the Environment called on an unusual type of expertise to try to measure the attractiveness of the new urban landscapes the festivals engendered. A group of landscape architects was hired to visit each of the sites of the four previous garden festivals and score the sites numerically on visual "improvement." These scores were then correlated with questionnaires from local residents and businesses to try to assess how frequently they were "exposed" to the view. Liverpool's former festival site, for example, had a relatively low initial score for visual improvement, but it was improved by the fact that a higher percentage of the city's population drove along Riverside Park, a major through road with views of the site. ${ }^{30}$

\footnotetext{
${ }^{24}$ Jones, 50,000 Bluebells, 9.

25 "It's Begun!," Gwent Gazette, 7 May 1992, Gwent Archives, Ebbw Vale. (Hereafter this repository is abbreviated as GA).

${ }^{26}$ Jane Porter, "Enter Ebbw Vale,” Landscape Design, July 1990.

${ }^{27}$ For descriptions of the festival tram network, see Glasgow Garden Festival, Glasgow Garden Festival 1988: Souvenir Brochure and Official Guide (Glasgow, 1988).

28 "Feasibility Study for a National Garden Exhibition in Stoke-on-Trent," 7 August 1981, TNA BD 40/ 296.

29 "Guest Editorial Note: Green Towns and Cities: Fantasy or Necessity?," Town Planning Review 55, no. 3 (1984): 261-64. See also Richard Stiles, "Green Cities," Architectural Review, June 1984.

${ }^{30}$ Department of the Environment, Evaluation of Garden Festivals, 25.
} 
The environmental critique implicit in Britain's garden festivals-a critique that pitted the organic against the industrial—belied the micromanaged artificiality of the new spaces that were created. This was a politics of the environment that was concerned with development rather than preservation and looked forward rather than backward. The approach to nature was one of breezy constructivism. At the same time that the healing powers of "nature" were invoked, the natural environment was also being presented as something to be reengineered and then hastily disposed of. ${ }^{31}$ In both Liverpool and Glasgow, most of the plants were grown off-site and transferred to the festivals shortly before they were due to open. ${ }^{32}$ In Liverpool, this process involved growing plants in a gigantic cold storage warehouse, part of the infrastructure of what remained of the city's docks, to produce an artificial winter long enough to extend the planting season. ${ }^{33}$ Meanwhile, faced with the sometimes gale-force winds sweeping in from the Mersey, the organizers were forced to create an entirely new physical environment. A range of hills built out of the rubble and refuse from the reclaimed site were constructed along the riverbanks to shelter the site from the wind. Scale models of this environment were tested before construction in a wind tunnel offsite. ${ }^{34}$

Tensions between the organic and the artificial were most extreme at the Ebbw Vale festival. The former steel-making town, serviced by the coalfields of the Welsh valleys, hosted the only festival held in a small town rather than a substantial city. Despite its proximity to the countryside, the festival fabricated a theme park-like exhibition to advertise the surrounding natural beauty, employing a fleet of robotic animals and birds, a life-size model of the celebrity botanist David Bellamy, a replica seaside pier (despite the town being twenty-five miles inland) and even a "smellorama" to recreate the smells of rural Wales. ${ }^{35}$ When a focus group of potential visitors to the Ebbw Vale festival was assembled by the festival's organizers a few years prior to its opening, they were shown television ads for Thorpe Park and Alton Towers, two of Britain's largest theme parks, alongside an advertisement for the festival. When asked to comment on plans for the festival, one of the focusgroup participants said, "We all know what Ebbw Vale looks like-and it doesn't look like that." 36

The emergence of "the environment" as an object of politics and calculation pertaining to the relationship between the human and the nonhuman, linking issues such as ecology, pollution, wildlife management, and climate change, has been

\footnotetext{
${ }^{31}$ For a critique of an environmentalism grounded in a belief in the constructedness of "nature," see Andreas Malm, The Progress of This Storm: Nature and Society in a Warming World (London, 2018), esp. 21-78; Joel Wainwright and Geoff Mann, Climate Leviathan: A Political Theory of Our Planetary Future (London, 2018), esp. 99-129; Naomi Klein, This Changes Everything: Capitalism vs. the Climate (London, 2014), 256-93. For the origins of the strategic use of landscaping and green spaces to reinvent postindustrial urban space, see Louise A. Mozingo, Pastoral Capitalism: A History of Suburban Corporate Landscapes (Cambridge, MA, 2011); John M. Findlay, Magic Lands: Western Cityscapes and American Culture after 1940 (Oakland, 1992), 117-60.

32 Jones, 50,000 Bluebells, 16; "Festival Takes Root," Glasgow Herald, 28 April 1988.

${ }^{33}$ Jones, 50,000 Bluebells, 16.

34 "Landform," International Garden Festival: Liverpool '84 press release, 22 June 1982, Liverpool Records Office, HQ 635 INT.

35 “12 Weeks!," Gwent Gazette, 6 February 1992, GA.

36 "Garden Festival Wales: Consumer Response to the Launch Commercial," 2, GA, 3481 M1 52/62/5/ 7,7 .
} 
dated to different moments in the twentieth century. ${ }^{37}$ The word environment was everywhere in the publicity for the festivals, and indeed, the festivals were supervised by the Department of the Environment, a ministry created in 1970 to oversee a mixture of urban planning, transportation, and conservation. The festivals, however, invoked an environmental politics different from that which had emerged to critique the measurable imprint that humans made on the natural world. Instead of an invisible and structural totality of relations negatively altered by economic and political growth, the environment invoked by national garden festivals was immediate, tactile, and sensory. This was a third way of thinking about the relationship between humans and nature, one that was not bound up either with the structural challenges of climate change gathering force in the 1980s or with the older Conservative undertow of conservation and rural protection. ${ }^{38} \mathrm{Or}$, to use the distinction advanced by the philosopher Kate Soper, the festivals put forward a view of nature that was neither "critically targeted on its human plunder and destruction" nor mobilized in service of the "ideological naturalization of social and sexual relations." 39 The garden festivals' history is another instance of how, in the words of Chris Otter, British environmentalism had by the end of the twentieth century become a "protean concept" wholly compatible with and operating as a subtle metaphor for neoliberal economics. ${ }^{40}$ Like the free market itself, flowers, trees, and grass would grow and spread in ways that could be loosely cultivated (rather than deliberately prescribed) by planners and politicians.

\section{ENTREPRENEURIAL GOVERNMENT}

National garden festivals were products of the unique political and economic conditions in which they emerged. However, they were also variations on a type of event that had more than a century of precedent in the industrial and trade expositions organized by nineteenth- and twentieth-century imperial economies. Such events dated from the Europe of the 1840s and 1850s, when industrializing states would showcase their technological dynamism at a time of interimperial competition, allowing citizens to marvel at cutting-edge advances in manufacturing. The nineteenth-century industrial exhibition complex found its most dramatic and precocious form in the Great Exhibition held in London's Hyde Park in 1851. ${ }^{41}$

\footnotetext{
${ }^{37}$ See, for example, Timothy Mitchell, Carbon Democracy: Political Power in the Age of Oil (London, 2013), 173-200; Kate Soper, What Is Nature? Culture, Politics and the Non-Human (Oxford, 1995); Jedadiah Purdy, After Nature: A Politics for the Anthropocene (Cambridge, MA, 2015); Paul Warde, Libby Robin, and Sverker Sörlin, The Environment: A History of the Idea (Baltimore, 2018); Donald Worster, Nature's Economy: A History of Ecological Ideas (Cambridge, 1985).

${ }^{38}$ For an older politics of rural conservation, see David Matless, Landscape and Englishness (London, 2016); Paul Readman, Storied Ground: Landscape and the Shaping of English National Identity (Cambridge, 2018).

${ }^{39}$ Soper, What Is Nature?, 3-5.

${ }^{40}$ Chris Otter, "Liberty and Ecology: Resources, Markets, and the British Contribution to the Global Environmental Crisis," in The Peculiarities of Liberal Modernity in Imperial Britain, ed. Simon Gunn and James Vernon (Berkeley, 2011), 182-98, at 196. For an intellectual history of ideas about the environment held by neoliberal economists, see Troy Vettese, "Limits and Cornucopianism: A History of Neo-liberal Environmental Thought, 1920-2007” (PhD diss., New York University, 2019).

${ }^{41}$ For the definitive history of this event, see Jeffrey A. Auerbach, The Great Exhibition of 1851: A Nation on Display (New Haven, 1999); see also Jeffrey A. Auerbach and Peter H. Hoffenberg, eds., Britain, the
} 
The event attracted an estimated six million people and displayed various new tools and products from Britain's emerging manufacturing economy. ${ }^{42}$ Similar events included the 1855 Exposition Universelle in Paris, the 1892 Chicago World's Fair, and the 1938 Glasgow Empire Exhibition, which was frequently invoked as a precedent during the Glasgow Garden Festival (held on the earlier exhibition's fiftieth anniversary). ${ }^{43}$ By the end of the nineteenth century, these events had crystalized into a recognizable set of tropes: usually a handful of architectural and artistic set pieces combined with dramatic displays of new technological advances and exotic artifacts from around the world. The events tended to be didactic, heavyhanded and drenched in teleological significance. Nowhere was this more the case than during the 1951 Festival of Britain. Occupying a central stretch of the South Bank of the Thames and visited by more than twelve million people, the festival marked a moment of celebratory self-reflection at a crucial moment in the forging of a developmental postwar state. ${ }^{44}$ The Festival of Britain was also consciously invoked by the national garden festivals: a memo circulated within the Department of the Environment described them as "smaller scale festivals of Britain. ${ }^{\prime 45}$

Despite such comparisons, national garden festivals had no such master narrative. Instead, they were minimalist grids, planned for the attraction of content from elsewhere. Other than an implicit valorization of the redemptive powers of nature, organizers of the festivals made few substantial claims of what exactly the festivals would end up looking like, providing only a master plan as well as basic facilities. David Harvey has argued that cities in the global north in the late twentieth century have been characterized by a shift from managerial to entrepreneurial forms of governance. Where once municipal authorities had existed to own and maintain infrastructure and housing, he maintains, from the 1980s they were increasingly forced to compete against one another to attract private capital to do this work. ${ }^{46}$ That the look and feel of urban space would be decided on the basis of market competition, and that that those nominally in charge of the built environment were now mostly tasked with clearing away past ruins and waiting for market forces to do the rest, is the second element of the late twentieth-century city that national garden festivals put on display for millions.

Garden festivals were one of many measures introduced by Margaret Thatcher's government in the early 1980s to attract private capital back into cities to aid the

Empire, and the World at the Great Exhibition of 1851 (Aldershot, 2013); Louise Purbrick, ed., The Great Exhibition of 1851: New Interdisciplinary Essays (Manchester, 2001).

${ }^{42}$ Auerbach, The Great Exhibition, 1.

${ }^{43}$ William Cronon, Nature's Metropolis: Chicago and the Great West (New York, 1992), 341-71; John E. Findling, Chicago's Great World's Fairs (Manchester, 1994).

${ }^{44}$ Becky E. Conekin, The Autobiography of a Nation: The 1951 Festival of Britain (Manchester, 2003).

${ }^{45}$ J. A. Colley to W. P. Roderick, "National Garden Exhibitions," 21 January 1981, TNA, BD 40/296.

${ }^{46}$ David Harvey, "From Managerialism to Entrepreneurialism: The Transformation of Urban Governance in Late Capitalism,” Geografiska Annaler, Series B: Human Geography 71, no. 1 (1989): 3-17. For examples of historical accounts of how this way of conceiving the city played out in different national contexts, see Kim Phillips-Fein, Fear City: New York's Fiscal Crisis and the Rise of Austerity Politics (New York, 2017); Aihwa Ong, Neoliberalism as Exception: Mutations in Citizenship and Sovereignty (Durham, NC, 2006), 97-121; Christophers, New Enclosure; Wetherell, "Freedom Planned." 
work of urban regeneration. ${ }^{47}$ Indeed, before being granted permission for a garden festival, Stoke-on-Trent had previously applied for and been denied both an enterprise zone and designation as an assisted area, a history suggesting that garden festivals were seen as one of many different options for postindustrial cities desperately seeking forms of aid from the central government. ${ }^{48}$ Entrepreneurial urban policies introduced in the early years of Thatcher's premiership included enterprise zones (1981), which were miniature tax havens created in poor neighborhoods to stimulate inward private investment; urban development grants (1982), which delivered small amounts of public money to local authorities only on the condition that it was spent on specific projects completed in partnership with the private sector; and derelict land grants (1983), which used public money to clear away decaying industrial ruins and prepare land for private development. Many of these new policies were managed and implemented by urban development corporations - unelected planning authorities that resembled the development corporations used to plan new towns between the 1940s and the 1990s. Urban development corporations had the power to buy and sell land and develop new infrastructure networks, all without oversight from elected local authorities. ${ }^{49}$ Their boards were appointed directly by the Ministry of the Environment and usually made up of business leaders and local politicians. Regional development agencies (such as the Scottish and Welsh Development Agency) were created to do similar work on a larger scale. Michael Heseltine, in a report that responded directly to the urban unrest in Liverpool in the summer of 1981, made it clear that the attraction of private capital by any means necessary was the guiding principle behind his government's plans to restore the economic base of Britain's cities. ${ }^{50}$

Urban or regional development corporations were put in charge of planning three out of five of the garden festivals. Their presence was most dramatically felt in Liverpool, where Militant Tendency, the Trotskyist wing of the Labour Party, controlled the city council after 1983. Liverpool Council repeatedly and pointedly opposed the Conservative government in the 1980s and refused to set a budget in 1985 as a protest against government spending cuts. ${ }^{51}$ The Merseyside Development Corporation was a means for Westminster to overrule Liverpool's elected local government during this period, and the garden festival went ahead in spite of protestations from the local authority. The council, which was originally tasked with joint management of the festival site, pulled out of the project, objecting to its cost. ${ }^{52}$ In Liverpool, then, the festival was a beachhead of central government control, an exclusion zone in which the elected local authority could not intervene.

\footnotetext{
${ }^{47}$ Nicholas Deakin and John Edwards, The Enterprise Culture and the Inner City (London, 1993); Michael Parkinson, “The Thatcher Government's Urban Policy, 1979-1989: A Review," Town Planning Review 60, no. 4 (1989): 421-40. Saumarez Smith, "Action for Cities."

48 Theokas, Grounds for Review, 158.

${ }^{49}$ Deakin and Edwards, Enterprise Culture, 38-39. For urban development corporations in the United States performing similar roles, see Lizabeth Cohen, Saving America's Cities: Ed Logue and the Struggle to Renew Urban America in the Suburban Age (New York, 2019), 255-311.

${ }^{50}$ Michael Heseltine, report to Margaret Thatcher, "It Took a Riot," August 1981, TNA, T 430/29.

${ }^{51}$ Andrews, "Decline and the City," chap. 6; Michael Parkinson, Liverpool on the Brink: One City's Struggle against Government Cuts (Hermitage, 1985).

52 Phil Miller, "Garden Festival 'Can Get By without City," Liverpool Daily Post, 7 October 1982.
} 
As the festivals were planned by entrepreneurial urban and regional development bodies whose criterion for success was the attraction of private capital, competitive outsourcing became a central ethos of the events. The large number of separate gardens that formed most of their exhibition spaces were not planned by festival organizers. Instead they were designed by various public and private bodies, including banks, local councils, and overseas national delegations. Many elements of the Liverpool festival were decided on by open competitions advertised to the public. Organizers encouraged amateur gardeners to submit entries for plots, and a jury of experts chose the winners. ${ }^{53}$ One garden was ceded to the children's television program Blue Peter, and almost twenty thousand young viewers competed to design the site. ${ }^{54}$ Another competition held among children was to name the festival's centerpiece pub, The Britannia, while a local fabric company won a contract to manufacture "Oliver," the soft toy representation of the festival's official logo. ${ }^{55}$

More significantly, the festivals also outsourced advertising space, events, and much of their physical infrastructure to numerous corporate sponsors. For the Festival of Britain, all corporate sponsorship had been banned from the festival's primary site on the South Bank of the Thames. ${ }^{56}$ In contrast, each of the five national garden festivals was a dizzying riot of sponsorship, and the festivals were effectively clearing houses for different private-sector contracts. The Liverpool festival's steam train was sponsored by NatWest Bank, an ominous portent of the privatization of Britain's railway system still eight years in the future. ${ }^{57}$ The site also featured a photographic trail, sponsored by Kodak, in which visitors would be loaned branded cameras for a tour of a small patch of manufactured parkland with twelve marked spots to take photographs. ${ }^{58}$ The children's playground, meanwhile, featured a large slide in the shape of a Pepsi can. ${ }^{59}$

The Ebbw Vale festival was likewise characterized by corporate sponsorship deals and private contracts. A children's play area entirely sponsored by Cadbury's featured a Cream Egg Switchback and a Flake Bar Tire Climber. ${ }^{60}$ Educational packs produced by the festival for school trips were sponsored by McDonald's, and there were negotiations for the fitness week held at the festival to be sponsored by the private health-care company (and rival to the National Health Service) BUPA.61 The festival hired Golly Slater, a professional marketing company, to develop nationwide advertisements and hold presentations about the festivals to court new corporate sponsors in places as far away as Japan. ${ }^{62}$ In the years leading up to the event, Golly Slater held focus groups to test the public's reaction to almost every element of the festival, even noting responses to Gryff, a cartoon character that became the

53 “[Liverpool] Festival Guide," 35.

54 "[Liverpool] Festival Guide," 49.

55 Jones, 50,000 Bluebells, 12.

${ }^{56}$ Conekin, Autobiography of a Nation, 205.

${ }^{57}$ Jones, 50,000 Bluebells, 53

58 “[Liverpool] Festival Guide," 33

59 "It's Magic for the Children in a Garden That's Made for Giants," Liverpool Echo (Festival Supplement), 21 May 1984.

60 "Monster Cuppa!," Gwent Gazette, 19 March 1992, GA.

${ }^{61}$ Marketing Steering Group: Contact Report, 8 November 1991, GA, 3481 M1 52/62/5/7.

${ }^{62}$ Marketing Steering Group: Contact Report, 13 September 1991, GA, $3481 \mathrm{Ml}$ 52/62/5/7. 
festival's official mascot. ${ }^{63}$ The language and practices of the private sector seeped into the festivals' organization. Throughout the planning of the Ebbw Vale festival, visitors were referred to as "consumers" and the event itself was deemed a "product." 64 Some of Ebbw Vale's exhibits were little more than giant advertisements. The festival's "environmental pavilion," for example, was sponsored by the domestic appliance company Hoover and promised "a light-hearted but educational look at the way in which Hoover domestic appliances not only tackle household cleaning, but are designed with environmental concerns in mind."65

Of all the festivals, it was perhaps Glasgow that had the largest corporate presence. The festival witnessed more than 1,250 individual instances of corporate sponsorship, ranging from the Bell's Whiskey Footbridge to the Coca-Cola Roller Coaster to the 240-foot Clydesdale Bank Anniversary Tower. ${ }^{66}$ While public-private partnerships, often organized by competition, played a significant role in planning in Britain in the twentieth century, conspicuous private sponsorship structured everything about of the look and feel of garden festivals. ${ }^{67}$ An ad for Glasgow's festival, distributed among interested corporations, stated, "We invite commercial involvement on an extraordinarily wide and flexible scale. . . every element of the Festival is sponsorable."68

Among the most significant instances of privatization on display at garden festivals were the many exhibits hosted by private house-building companies. It is worth dwelling on these in detail, as they, more than anything else, contributed toward the banal normalization of a privatized and decentralized urban environment-a projection of a contingent and still much contested political moment into the distant future. The festivals coincided with a significant change in the nature and provision of Britain's housing stock. The 1980s had seen the effective end of a state-led public housing project that began in earnest between the two world wars. The passage of the 1980 Housing Act by Margaret Thatcher's new Conservative government financially incentivized residents to purchase their own homes and led to a rapid privatization of this housing stock. In the six years after the 1980 act was passed, more than 800,000 council houses were purchased by their current occupants. ${ }^{69}$ In the 1960s and 1970s, local authorities were building an average of 157,000 new council homes each year.

\footnotetext{
${ }^{63}$ Golly Slater and Partners, "Presentation to Garden Festival Wales," 17 October 1990, GA, 3481 MI $52 / 62 / 5 / 7$.

${ }^{64}$ Slater and Partners, "Presentation."

65 "Monster Cuppa!"

${ }^{66}$ This figure was arrived at by counting the list of sponsors published in the index of the festival's official guide, Glasgow Garden Festival 1988. It is worth emphasizing that this figure is the total instances of sponsorship, rather than number of individual sponsors.

${ }^{67}$ Peter Shapely, "Governance in the Post-war City: Historical Reflections on Public-Private Partnerships in the UK," International Journal of Urban and Regional Research 37, no. 4 (2013): 1288-304. For the role of the private sector in 1960s urban redevelopment schemes, see Otto Saumarez Smith, Boom Cities: Architect Planners and the Politics of Radical Urban Renewal in 1960s Britain (Oxford, 2019); Peter Mandler, "New Towns for Old: The Fate of the Town Centre," in Moments of Modernity: Reconstructing Britain, 1945-1964, ed. Becky Conekin, Frank Mort, and Chris Waters (London, 1999), 208-27.

68 "Glasgow Garden Festival 1988 Advertising Brochure," Glasgow City Archives, GC 91414430079.

${ }^{69}$ Ray Forrest and Alan Murie, Selling the Welfare State: The Privatisation of Public Housing (London, 1988), 110.
} 
By 1988 , this figure had fallen to just $35,000 .{ }^{70}$ What remained of Britain's public housing stock by the end of the decade was mostly concentrated in inner city, high-density housing projects, which were difficult to privatize. While many of these developments had once offered working-class Britons an alternative vision of urban modernity, by the mid-1980s many had become spaces of last resort for councils and were increasingly denigrated by planners and politicians. ${ }^{71}$

Given this context, it is significant that the model housing exhibitions in the five garden festivals featured homes that were private, suburban, and detached. Liverpool festival's "Home and Garden Feature" was six detached suburban homes built by private developers such as Wimpey and Barratt. After the festival came to an end, these six houses were sold to members of the public and formed the basis of a suburb of more than a thousand homes, following the sale of part of the festival land to a private developer. ${ }^{72}$ Wimpey Homes also constructed a model village for visitors to the Glasgow Garden Festival. One of the more upmarket homes, "Lancefield Manor," was presented as belonging to a fictional aspirational family called (in one of the many small ironies of history) "the Blairs." Mr. Blair was a high-ranking publisher, his wife was a piano teacher, and their teenage daughter was an apprentice cello player. Their five-bedroom house included a gym, a spa bath, and a coherent fabric design created for Wimpey. ${ }^{73}$ In Ebbw Vale, meanwhile, a collection of private, detached show homes deemed the "town of the future" was turned into a large suburban community after the closure of the site, complete with a small shopping center and a business park. ${ }^{74}$ Needless to say, these homes of the future differed substantially from a comparable exhibition about the future of domestic life organized by the 1951 Festival of Britain, which showcased the Lansbury Estate, a comprehensively planned public housing developing in inner-city London that festival attendees were invited to tour. ${ }^{75}$ While the Lansbury exhibition conjured a future that was state built, collective, high density and resolutely urban, the model homes that were presented to garden festival visitors were private, suburban, and isolated, examples of the kinds of private, low-rise home-ownership being popularized and enabled by the new Conservative government and by entrepreneurial development corporations and vested with the same sheen of optimistic modernity.

With so much content outsourced, the festivals themselves had little to say, and, unlike the Festival of Britain, had no overarching master narrative or teleology. The plan for the Glasgow site, produced by the architecture firm Building Design Partnership, was a triumph of minimalist planning. The festival was divided into six broadly defined "themes" dispersed around a central core, so that no area of

${ }^{70}$ David Butler and Gareth Butler, British Political Facts, 10th ed. (Basingstoke, 2011), 377.

${ }^{71}$ See, for example, Anne Power, Property before People: The Management of Twentieth-Century Council Housing (London, 1987); Peter Malpass, Reshaping Housing Policy: Subsidies, Rents and Residualisation (London, 1990); Ravetz, Council Housing and Culture, part 3; John Boughton, Municipal Dreams: The Rise and Fall of Council Housing (London, 2018), 169-219.

72 "Home Is Where the Park Is," Liverpool Echo, International Garden Festival Pre-opening Supplement, 25 April 1984.

73 "Wimpey Homes Invites You to Lancefield Manor," advertising brochure, National Library of Scotland GSR 2/3.

74 "Jobs Pledge as 'Town of the Future' Unveiled," Gwent Gazette, 6 February 1992, GA.

${ }^{75}$ Conekin, Autobiography of a Nation, 153-56. 
the festival could be given preference over another. ${ }^{76}$ While garden festivals offered a handful of narratives of advancement or improvement-the Liverpool festival's "Land Treatment Maze," for example, built to showcase local environmental initiatives, or the "Silicon Glen" exhibit on the Glasgow site, showcasing technologysuch vivid illustrations of progress were relatively rare. This was particularly noticeable with regard to the festivals' relationship with history. In the form of the steam trains, trams, eighteenth-century sailing ships, pottery museums, and Beatles memorabilia, the past was represented at the festivals as an excuse for color and excitement rather than as a state of affairs altered by collective historical achievement-a chaotic pastiche rather than an ancien regime. ${ }^{77}$ That the festivals were designed to physically erase the recent industrial past of the inner city, only to themselves be erased by property development after their closure, deepened this feeling of transience.

Although garden festivals prioritized miscellany and noise over narrative coherence, forms of explicit political dissent were forbidden. A controversy briefly ignited over a garden plot outsourced to a radical landscaping group called The Diggers, whose name derived from the proto-communist seventeenth-century sect. The group originally intended to build a fiberglass pond, from which a hand would emerge holding a UB40 form (a form which all of those claiming an unemployment benefit had to complete). The group intended the exhibit to be a protest against the high levels of unemployment in Liverpool in the early 1980s and an implicit critique of Margaret Thatcher's government. ${ }^{78}$ The design was vetoed by the festivals' organizers; instead, The Diggers were asked to produce an interactive "Quiz" garden about local trivia-deemed to be a safer and less confrontational option. ${ }^{79}$ Meanwhile, an application by the Campaign for Nuclear Disarmament for a garden plot at Liverpool's festival was denied by the Department of the Environment on the grounds that it was "improper" for the festival to "include a political element." 80

As with the market environmentalism described above, the willingness for organizers to outsource festival content implied an implicit skepticism about the ability of a single body to plan a coherent and totalizing urban environment or make new kinds of citizens. ${ }^{81}$ Organizers looked instead to the hidden hands of market forces or the green fingers of nature to do this work. The exclusion of forms of political dissent, however, showed that there were limits to this competitive order. While the festivals

${ }^{76}$ George Mulvagh et al., "The Challenge of Designing for Fun,” Landscape Design, June 1988.

${ }^{77}$ For some reflections on heritage and the emergence of this way of thinking about history, see Daniel T. Rodgers, Age of Fracture (Cambridge, MA, 2011), 221-56; Patrick Wright, On Living in an Old Country: The National Past in Contemporary Britain (Oxford, 2009); Raphael Samuels, Theatres of Memory: Past and Present in Contemporary Culture (London, 2012).

${ }^{78}$ Laura Davis, "Flower Power," Liverpool Daily Post, 2 December 2006.

79 Davis, "Flower Power."

${ }^{80}$ Memo, M. R. Fawcett to Mr. Peck, 17 August 1983, TNA, AT 81/307.

${ }^{81}$ Historians of Britain are increasingly drawing attention to the ways that the politics of the 1980s were characterized by forms of individualism and autonomy that manifested as a skepticism toward state planning. For the emergence of "popular individualism" in late twentieth-century Britain, see Emily Robinson et al., "Telling Stories about Post-war Britain: Popular Individualism and the 'Crisis' of the 1970s," Twentieth Century British History 28, no. 2 (2017): 268-304. For theories of the individual in 1980s Conservative policy making, see Aled Davies, James Freeman, and Hugh Pemberton, "'Everyman a Capitalist' or 'Free to Choose'? Exploring the Tensions within Thatcherite Individualism," Historical Journal 61, no. 2 (2018): 477-501. 
might not have spun their inchoate elements into a coherent narrative, they still operated with an implicit vision of British society and its relation to the wider world.

\section{POSTIMPERIAL INTERNATIONALISM}

Although the Liverpool Garden Festival was held in 1984, the event was conceived during the summer of 1981, months that saw widespread urban unrest in Britain's inner cities, mostly among those cities' black populations. While there had been pitched battles between police and residents in Brixton in London, Handsworth in Birmingham, Moss Side in Manchester, and Chapeltown in Leeds, the events in the Toxteth neighborhood of Liverpool were arguably the most consequential and the most intensively policed. Liverpool's imperial maritime history meant that the city had the one of the oldest, most established black communities in Britain, dating back to the influx of West African merchant seamen in the late nineteenth and early twentieth centuries and in some instances to former enslaved people who had won their freedom fighting in the American War of Independence. ${ }^{82}$ By the beginning of the 1980s, harassment of Toxteth's black community by a police force that had just four black officers out of a total of five thousand was all too common. ${ }^{83}$ Controversial "sus" laws allowed police to stop and search anyone they suspected of being criminals, resulting in racial profiling and resentment. The police were accused of framing young black residents for drug offences and holding competitions to see who could be the first to arrest a black person. Meanwhile, the erosion of Liverpool's employment base had been felt particularly acutely by the city's black population, with black unemployment in the city doubling in the ten years before $1981 .{ }^{84}$ The uprising began after the heavy-handed arrest of a young black man, Leroy Cooper, by the Merseyside Police on 3 July. Over the following days, the impoverished neighborhood fought pitched battles against the police, effectively seceding from the rest of the city, and on 6 July, the police, becoming increasingly desperate, fired dozens of CS gas grenades, the first and only time that tear gas had been used in the country outside of Northern Ireland. ${ }^{85}$

Across Britain, such events called attention to the way that Britain's mid-twentiethcentury developmental state had been profoundly structured by racial inequalities. As in other areas of the country, Liverpool's black residents had been either effectively excluded from or occupied a subordinate place within the state-constructed apparatus of health care, comprehensive education, and public housing that had underwritten social mobility for many of its white citizens. ${ }^{86}$ Meanwhile, as Britain decolonized,

\footnotetext{
${ }^{82}$ For Liverpool's black history, see Jacqueline Nassy Brown, Dropping Anchor and Setting Sail: Geographies of Race in Black Liverpool (Princeton, 2005); John Belchem, Before the Windrush: Race Relations in 20th-Century Liverpool (Liverpool, 2014).

${ }^{83}$ Figure cited by the journalist Andy Beckett in his account of the uprising: Andy Beckett, Promised You a Miracle: UK80-82 (London, 2015), 61. See also Simon Peplow, Race and Riots in Thatcher's Britain (Manchester, 2019), 152-72; Diane Frost and Richard Phillips, eds., Liverpool '81: Remembering the Riots (Liverpool, 2011).

${ }^{84}$ Peplow, Race and Riots in Thatcher's Britain, 152.

${ }^{85}$ Erik Linstrum, "Domesticating Chemical Weapons: Tear Gas and the Militarization of Policing in the British Imperial World, 1919-1981,” Journal of Modern History 19, no. 3 (September 2019): 557-85.

${ }^{86}$ Selected works on exclusive practices along the lines of race within Britain's welfare state include Perry, London Is the Place for Me; Roberta Bivins, Contagious Communities: Medicine, Migration, and the NHS in
} 
new legislation in 1962, 1968, 1971, and 1981 tightened Britain's borders, sealing the country off from its former empire and in doing so further securing its social infrastructure from the claims of former colonial subjects. ${ }^{87}$

Shortly after the fires in Toxteth were extinguished, the Conservative Party leadership descended on Liverpool. First came Margaret Thatcher herself, who met briefly with the police and with community leaders in the late summer of 1981. Shortly afterward came Michael Heseltine, who spent two weeks in Liverpool subjecting himself to a breathless schedule of public meetings. ${ }^{88}$ While as early as 1979 the Department for Environment had shown a tepid interest in West German Bundesgartenschau, the announcement of national garden festivals and the selection of Liverpool as the first host came shortly after Heseltine's visit and was framed within the context of the Toxteth uprising. When the festival opened three years later, however, it was an affluent and largely white affair. The Department of the Environment carried out surveys of attendees and found the average visitors to be wealthierthan-average families with young children; the ministry's surveys kept records of the class, gender, age, and hometown of visitors, but, tellingly, recorded no information about race or ethnicity. ${ }^{89} \mathrm{It}$ is hard to comment on an absence, yet it seems clear that, despite the festival's origins, its target audience was not the residents of Toxteth. A suggestion raised in Parliament by Robert Parry, a Labour MP representing Liverpool, that unemployed people be offered discount tickets to the festival was considered by the Merseyside Development Corporation-and rejected. ${ }^{90}$ Meanwhile, nonwhite faces were strikingly absent from both the festival's promotional material and the sculptures of "typical" Liverpudlians dotting the festival's riverside walk. ${ }^{91}$ Indeed, Liverpool's historic black community did not feature at all in the various ways the city was represented throughout the course of the festival-with a focus on mostly local icons such as The Beatles, the docks, and the mythical liver bird. The festival also painted a nostalgic picture of the city's eighteenth- and nineteenth-century Atlantic maritime history, with fleets of tall ships sailing from Nova Scotia to Liverpool to dock at the festival at set times, and benches made from West Indian timber recycled from the piers of the Herculaneum Dock. ${ }^{92}$ The trade in enslaved people, a foundational element of this history, went unmentioned.

Post War Britain (Oxford, 2015); Beverley Bryan, Stella Dadzie, and Suzanne Scafe, The Heart of the Race: Black Women's Lives in Britain (London, 1985); Jordanna Bailkin, The Afterlife of Empire (Berkeley, 2012); Waters, Thinking Black; Kathleen Paul, Whitewashing Britain: Race and Citizenship in the Postwar Era (Ithaca, 1997).

${ }^{87}$ Nadine El-Enany, Bordering Britain: Law, Race and Empire (Manchester, 2020). See also Perry, London Is the Place for Me, 48-89; James Vernon, "Heathrow and the Making of Neoliberal Britain," Past and Present, 22 January 2021, published ahead of print, https://doi.org/10.1093/pastj/gtaa022; Callum Williams, "Partiality, Work Permits and the European Economic Community: The Introduction of the 1971 Immigration Act," Contemporary British History 29, no. 4 (2015): 508-38.

${ }^{88}$ Michael Heseltine, Life in the Jungle: My Autobiography (London, 2001), 209-36.

89 "Survey of Visitors to the Liverpool Garden Festival: Final Report," Liverpool Records Office, HQ 712.5 NOP. The survey recorded that 54 percent of adult visitors were from ABCl (white collar) households (compared with 39 percent across the country as a whole), and that only 9 percent of visitors were ages 15 to 24 (compared with 16 percent nationally).

${ }_{90}$ Hansard Parliamentary Debates, Commons, 6th series, 29 February 1984, vol. 55, c237.

${ }^{91}$ Jones, 50,000 Bluebells, 24.

92 Jones, 9, 46; “[Liverpool] Festival Guide," 198-99. 
Liverpool's festival, however, was far from parochial. Indeed, it invoked the entire world. Planned by the Merseyside Development Corporation and commissioned by the Thatcher government, it was also overseen by an international agency called the Bureau International des Expositions. The agency was founded in Paris in 1923 to bring order to the increasing number of industrial trade expositions being held across the industrialized world. It assessed bids from different national governments to host officially recognized national expositions, meaning that by the mid-twentieth century, national exhibitions had become globally standardized affairs. Liverpool's festival was officially approved as an Al event, the agency's most prestigious category. ${ }^{93}$ With this backing, the Liverpool festival called into being a peculiar global community on the banks of the Mersey, with plots of land and exhibition status awarded to more than thirty different nations. These included Japan, India, the United States, West Germany, Portugal, Sri Lanka, Australia, Denmark, Thailand, and Israel. Communist China, still relatively closed to the world, also participated, a fact touted as a major diplomatic breakthrough. ${ }^{94}$ Behind the scenes, however, the Chinese Embassy in London was reportedly critical of the "slipshod" nature of China's exhibit, which, some officials claimed, was not as impressive as the neighboring Japanese garden. ${ }^{95}$

Each participating country was obliged to provide activities to fill hundreds of hours of scheduled events. The result was an absurdist internationalist bricolage, featuring Chinese lion dancing, totem-pole carving, mock American pop concerts, and a "Japanese kimono laser spectacular." 96 Many of the overseas delegates were patronized in the print material produced by the festival and treated as strange curiosities. The Chinese presence in the festival, for example, became an object of derision in a children's book used to publish the festival. It was narrated by two cartoon birds: "[The Chinese workers] even bought their own cook with them, but they didn't leave much for us did they?" "To be honest, my friend, I can't say I'm sorry; I don't fancy the idea of eating bird's nest soup!'97 Yet Liverpool had a significant and established Chinese community, most of whom had arrived through merchant shipping networks beginning in the mid-nineteenth century. Chinese Liverpudlians had been subject to intensive forms of policing and aggressive deportation drives in the first decade of the twentieth century and again in the 1940s, an often-overlooked chapter in the city's history. ${ }^{98}$ Although the festival offered a random and theatrical cosmopolitanism, organized on a global scale by an international agency, it failed to challenge much older racial hierarchies that continued to structure Britain's social order. ${ }^{99}$

93 Theokas, Grounds for Review, 10.

94 "Worldwide Lure of the Greenest Show on Earth," Liverpool Echo (Festival Supplement), 21 September 1983.

${ }^{95}$ Memo, C. H. Stubbs, 4 July 1984, TNA, FCO 21/2705.

96 "[Liverpool] Festival Guide," 188.

${ }^{97}$ Peter Wynn Jones, Oliver and Simon at the International Garden Festival: Liverpool '84 (Liverpool, 1984), n.p.

98 Belchem, Before the Windrush, 28-33, 125-30.

${ }^{99}$ In this sense, Liverpool's festival represented a shallow and consumer-orientated form of what came to be known as multiculturalism, similar to that described by Elizabeth Buettner in the context of South Asian food. Elizabeth Buettner, "Going for an Indian': South Asian Restaurants and the Limits of Multiculturalism in Britain," Journal of Modern History 80, no. 4 (2008): 865-901. 
While the festival may have offered little to attract the city's unemployed residents, great effort was made to attract tourists from all over the world. Prior to the festival, delegations from city council and the Merseyside Development Corporation contacted and in some cases even visited various international cities to drum up support, including Cologne and Odessa, as well as other Liverpools in New York, Canada, and Australia, and the residents of Liverpoolstrasse in Berlin. ${ }^{100}$ Competitions across the world were held to win flights to Liverpool, and the festival initiated the redevelopment of city's airport. ${ }^{101}$ Five thousand visitors from the south of England paid for a luxury train journey to the festival aboard a replica of the Oriental Express. ${ }^{102}$

The other four festivals were equally focused on tourism. The organizer of the Glasgow festival described the event as "the single biggest tourist attraction staged in Scotland for half a century." ${ }^{\prime 03}$ Meanwhile, in Ebbw Vale, arguably the least globalized and by some degree the whitest of the five festival sites, a tourism industry had to be assembled out of almost nothing in the year preceding the event. The Wales Tourism Board was forced to launch a training program for prospective bed-andbreakfast proprietors living within a twenty-mile radius of the festival site. Training, mandatory for all 1,900 workers at the festival, included lessons in food hygiene and business planning. ${ }^{104}$

Garden festivals, therefore, invoked the world. They did so by marketing the auratic uniqueness of "place" rather than the abstract emptiness of "space."105 Local history was called upon to do some of this work of urban place-making. The centerpiece of the Glasgow festival was a representation of the city's Victorian high street, interspersed with life-sized sculptures of former residents. It was initially intended that more than one-fifth of the festival would be taken up with a complex of exhibits called "The Heritage of Glasgow." 106 Meanwhile, the organizers of the Liverpool festival sought to emulate the rebranding of New York through its "I Love New York" marketing campaign, a response to that city's fiscal crisis in the mid1970s, in conditions not dissimilar to those of Liverpool in the 1980s. ${ }^{107}$ In the wake of deindustrialization and a declining tax base due to suburbanization, New York restructured its finances, imposing a new regime of austerity and turning to entrepreneurial forms of management to attract jobs, capital, and tourists. ${ }^{108}$ In order to survive, many other postindustrial cities such as Liverpool and Glasgow were becoming experts in their own self-promotion, competing far and wide for a share of a global pool of tourists, jobs, and capital. In this new climate,

${ }^{100}$ Liverpool City Council Minutes, "International Garden Festival Working Party," 22 February 1983, Liverpool Records Office, 352 MIN/FWII, 2.

101 "All Set for Take-Off," Liverpool Echo (Festival Supplement), 23 November 1983.

102 “On Right Lines for Trip of a Lifetime," Liverpool Echo, Festival Supplement, 23 November 1983.

${ }^{103}$ Clipping, "Glasgow's Glory," Scotsman Magazine, April 1988, Glasgow City Archives, f607 344 1443.

104 “Support Tops $£ 500,000$ Mark," Gwent Gazette, 2 April 1992, GA.

${ }^{105}$ For theoretical work on attempts to manufacture "place" out of "space" for the strategic purpose of urban development, see Doreen Massey, For Space (London: 2005), 130-63; Doreen Massey, "A Global Sense of Place," Marxism Today, June 1991.

${ }^{106}$ Mulvagh et al., "Challenge of Designing for Fun," 26.

107 "Festival's End Is Just the Beginning," Liverpool Echo (Festival Supplement), 23 November 1983.

108 Phillips-Fein, Fear City, 292-94. 
garden festivals acted as giant promotional venues for their host cities, marketing them to millions in the hope of attracting residents, tourists, and businesses. ${ }^{109}$ In this sense, the festivals further standardized a set of urban practices becoming increasingly common across the world.

At national garden festivals, and particularly the Liverpool festival, the national seemed to disappear as the intermediary between the urban and the global. Through the marketing of place over space, the festivals announced the entry of cities like Liverpool and Glasgow into a global competition for tourists and capital. This vision of how British cities related to the world had no time for the old inequalities of empire. The festivals conjured a cosmopolitanism that was compatible with the segregated cities that lay out of sight beyond the festivals' turnstiles-a cosmopolitanism that welcomed the mobility of capital and tourists at same time as Britain's border regime intensified, even for its former imperial subjects and their descendants.

\section{CONCLUSION}

By 1990, support among the government and the public for garden festivals was waning. That year the Department of the Environment launched an investigation into the festivals' economic and environmental impacts. The findings were lukewarm, noting the complexities of quantifying any urban improvements led by the festivals and recognizing that while they may have had some success alongside other regeneration initiatives, the festivals alone had not met the ambitious expectations that had been set for them. ${ }^{110}$ In the wake of draining enthusiasm, the Department of the Environment discontinued the program, and so the 1992 Ebbw Vale festival was the last of its kind in Britain.

Indeed, national garden festivals did not succeed in their long-term aims of remaking the cities in which they were embedded. Nowhere was this failure more striking than in Liverpool. Although part of the festival land was later turned into a suburban housing complex, the rest of the site was largely abandoned. In the mid-1990s, it was occupied by an amusement park called Pleasure Island but it closed after just four years. By the early twenty-first century, the site was an overgrown and desolate landscape punctuated only by the ruins of a former theme park. Following the failures of the private sector to develop the site, the area was transferred in 2009 to the Land Trust, a nonprofit organization that reopened the former festival grounds as a nature preserve. With words eerily similar to those used to promote the original festival, the site's reopening was hailed by the local press as a "symbol of the city's rebirth."111

\footnotetext{
${ }^{109}$ For the way that cities have been reformed in the late twentieth century in order to compete globally for capital, see Saskia Sassen, The Global City: New York, London, Tokyo (Princeton, 1991); Harvey, "From Managerialism to Entrepreneurialism." For the recent reorientation of London's property market toward overseas investors, see Anna Minton, Big Capital: Who Is London For? (London, 2017). For a similar kind of a postimperial internationalism in the realm of urban planning, see Ortolano, Thatcher's Progress, esp. $184-212$.

110 Department of the Environment, Evaluation of Garden Festivals, 4.

111 Ben Schofield, "Site Could Be 'Symbol of City's Rebirth," Liverpool Daily Post, 26 September 2008.
} 
In Glasgow, too, the story of the after-use of the festival was not a happy one. Here again, the site was ultimately unpalatable to private investment. The various set-piece infrastructural components of the site were sold off and shipped elsewhere, including the 240-foot tower, which was sold to the Welsh seaside resort of Rhyl. ${ }^{112}$ Although the area was immediately sold to Laing Homes, a property developer, the company was unable to summon enough capital to build any houses. ${ }^{113}$ As in Liverpool, the failure of the market to capitalize on reclaimed land meant that a non-profit organization had to step in, in this case Scottish Enterprise (a rebranding of the same Scottish Development Agency which had helped organize the festival). Under Scottish Enterprise's management, the site has become a complex of museums and cultural attractions and hosts the headquarters of BBC Scotland. The smaller festivals of Stoke-on-Trent, Gateshead, and Ebbw Vale were only marginally more successful in developing their respective festival sites, with similar stories of delay and abandonment. All of the festivals saw their after-use affected by the recession of the late 1980s and early 1990s. While state-appointed urban and regional development corporations could clear and trim the land, invite tourists to visit it, and market it across the world, there was no guarantee that the land would thrive on the open market. While the soil on which future private capital would develop had been planted and fertilized, the eventual growth of future investment was stunted by the economic winter of the early 1990s.

Despite their subsequent dereliction, national garden festivals distilled many of the elements of a new type of urbanism that would be generalized across Britain by the millennium. The events were precocious, exceptional spaces that took on a sheen of modernity, where time seemed to be moving faster. As many have pointed out, this new type of city was not characterized by a retreat of the state from the business of urban management, or a significant reduction of net public spending outside of local authority housing departments. ${ }^{114}$ Indeed, one Liverpool councilor complained that the festival was "the most expensive job creation project since the space race." 115 Nevertheless, in Britain's garden festivals we can see a qualitatively different type of urbanism taking shape. First, they offered an environmental critique of factories, docks, warehouses, and mines that had formed Britain's economic base for much of the twentieth century, a critique grounded in a sensory revulsion at rotting buildings and leaking pollutants rather than the more invisible threat of carbon omissions. Second, they were venues whose content-whether infrastructure, services, logos, names, or ideas-was outsourced to the highest bidder. Finally, in their courting of tourists and overseas capital, the festivals contributed to the reordering of the relationship between the urban and the global in Britain, bypassing the nation-state and sidelining a preexisting social order shaped by the inequalities of empire.

The instigators of national garden festivals did not, of course, invent any of these three axes along which British urbanism was to be reimagined. Rather, the

\footnotetext{
112 Stephen Mcilkenny, “The Glasgow Garden Festival: A True Legacy or a Glorious Failure,” Scotsman (Edinburgh), 3 December 2016.

${ }^{113}$ Department of the Environment, Evaluation of Garden Festivals, 6.

${ }^{114}$ For arguments that late twentieth-century British urban policy has been characterized by an expansion rather a reduction of state money and power, see Jim Tomlinson, "De-industrialization Not Decline"; Saumarez Smith, "Action for Cities."

${ }^{115}$ Miller, "Garden Festival 'Can Get By without City."
} 
significance of the events lies in the way these features were assembled together for the first time to model an alternative vision for a postindustrial, postimperial urbanism. Despite their short-term failures, national garden festivals sowed the seeds for some of the elements that have become characteristic of early twenty-first century British cities. Like many across the global north, Britons are used to living in cities that weaponize nature in the service of economic development, whose governments have been reduced to clearing houses for the distribution of private-sector contracts, and which promote a cosmopolitanism that leaves older inequalities of empire untroubled. To many alive today, from Rotterdam to Baltimore, the 1984 Liverpool Garden Festival might feel like a familiar space, far more familiar than the docklands that it replaced. 